\title{
Solute Carrier Family 45 Member 3
}

National Cancer Institute

\section{Source}

National Cancer Institute. Solute Carrier Family 45 Member 3. NCI Thesaurus. Code C97793.

Solute carrier family 45 member 3 (553 aa, $~ 59 \mathrm{kDa}$ ) is encoded by the human SLC45A3 gene. This protein plays a role in transport. 